\title{
Banks Contribution to Promote Indonesian Financial Inclusion
}

\author{
Tri Handayani ${ }^{1 *}$, Lastuti Abubakar ${ }^{1}$ \\ ${ }^{1}$ Economic Law Department, Law Faculty, Universitas Padjadjaran, Bandung, Indonesia \\ *Corresponding author.Email: tri.handayani@unpad.ac.id
}

\begin{abstract}
The Micro Small Medium Enterprise (MSME) sector in several other countries is considered to be able to overcome unemployment, supporting the community to be able to prioritize entrepreneurship in order to create a sustainable business and even better if from the development of MSME businesses also can create job field. Banks as an intermediary institution can reduce the unemployment rate and can promote the economic growth. This research is conducted by normative juridical research method, which is focused on the examining the application of the rules or norms in positive law. The purpose of this study is to provide recommendations for improving financial inclusion in Indonesia. Result of this study is the financial inclusion allows people to save for family needs, borrow to support a business, or build a cushion against emergencies. Having access to financial services is an important step to reduce poverty and inequality. So, branchless banking is one of an alternative method to extend the distribution channel of financial products, offering an integrated distribution model that facilities consumer access to financial services
\end{abstract}

Keywords: financial inclusion, branchless banking, MSMEs

\section{INTRODUCTION}

Banks as creditor and capital lenders are now required to integrate the aspects of the social environment and governance into their main business, so nowadays banks not only manage the reputation and risk but also seek to realize a sustainable business transformation. Banks contribution as institutions can reduce the unemployment rate, which is increasingly rising in every year. Banks as one of financial services have an important role to promote the economic growth if banks available and affordable to the public. Based on this situation the Bank as a source of funding in business activity can provide a funding to the business priority sector such as to the Micro Small Medium Enterprises (MSMEs). The MSMEs in several other countries is considered to be able to overcome unemployment, supporting the community to be able to prioritize entrepreneurship in order to create a sustainable business and even better if from the development of MSME businesses also can create job field.

The critical contribution of MSMEs to broader social economic objectives, including job creation makes them a key priority area for achieving the Sustainable Development Goals (SDGs). Job creation through MSMEs will often directly benefit the poor and vulnerable, particularly women and youth, thereby directly reducing poverty, increasing income and positively impacting on household investments in education and health over time. [1]The Government can provide the access to credit for MSME is easier than before and reducing their cost of funds at the same time. This is the support from the government to MSMEs sector.

The world has seen increased growth in MSMEs following the 2008 financial crisis. While not yet having returned to pre-crisis levels, recent data from an OECD and World Bank survey suggests growth in MSMEs in countries such as the
UK, France and Sweden, which reflects positively on job creation. For instance, about half of MSMEs surveyed expect to increase employment in the short-term, especially for those created in less than three years [1].

Thus, the Bank is one of the economic pillars in Indonesia that can contribute to creating inclusive and sustainable economic growth. Based on these conditions, it is necessary to have financial sector policies that need to be reform or create in order to support the realization of an inclusive and sustainable Indonesian economy and to reduce unemployment in every year. The Financial inclusion is a response to the high groups of people included in the category 'In the bottom of pyramid' (low and irregular income, living in remote areas, people with disabilities, workers without legal identity documents and marginalized communities), and they are classified as unbanked / unbankable. Since 2010, World Bank have led the initiative for increase financial inclusion in developing countries to help reduce poverty levels in developing and emerging economies [2]

Financial inclusion is a sustainable provision with affordability of financial services so that it can bring the poor into the formal economic sector. Financial inclusion is also can be defined as the tools for the poor to formal financial services. [3] Financial inclusion causes an increase in the number of (poor) individuals who can have access to formal financial services especially through banks; this will contribute to poverty reduction and economic growth. With financial inclusion, individuals who were previously unreachable by formal financial services such as banks will have the opportunity to invest and launch businesses, and this will contribute to poverty reduction and help economic growth in Indonesia.

According to Indonesian Financial Services Sector Master Plan 2015-2019, the development objectives and direction of 
Financial services sector are to optimize the role of financial services sector to expedite national economic growth, to maintain financial system stability as the basis for sustainable development, enhancing public financial independence and supporting equitable economic development. The goal of national economic development is public prosperity, while overcoming in equality. At the end financial services sector should contribute in realizing public financial independence through financial inclusion. [4] Financial inclusion may be defined as the process of ensuring access to financial services and adequate credit where needed by vulnerable groups such as weaker sections and low income at an affordable cost.[5] Inclusive finance are includes access to financial products and services such as bank accounts, insurance, money transfer \& payment services, etc. This is giving individual the possibility to save for future stability, high bank deposit rates will enable a stable deposit base, opportunities to open savings, make investments and access credit.

Therefore, it is necessary to study further through mapping the regulations regarding banking sector policies in terms of realizing an inclusive and sustainable economy by optimizing the role of MSME to resolve the unemployment and to promote the financial inclusive. The ultimate goals from this matter are the society in all levels will have the same opportunity to use banking financial services.

\section{METHOD}

This research is conducted by normative juridical research method, which is focused on the examining the application of the rules or norms in positive law. [6] This research also used the positivist legist conception approach. This concept views the law as identical with written norms created and promulgated by authorized institutions.[7] The descriptiveanalytical method is making a systematic, factual, and accurate description of the facts. Therefore, this study examines and describes legal aspects of issues relating to banking law and SDG's. Rules-regulations, principles, and norms in banking law shall be the focus on this study. In addition, research method of this study not only use a legal history approach and comparative law but also uses secondary data and was obtained through documentary and literature study, then the data was collected and analyzed qualitatively

\section{RESULTS AND DISCUSSION}

In the era of rapid development of Information Technology (IT), financial technology also played a significant role in the future development of the banking industry. OJK provides the 2015-2019 Medium-Term Banking Policy Development Direction. Things that are the focus of the FSA in the development of the banking industry in the medium term are consist:

a. To optimize the role of banks in supporting food endurance, energy and other priority sectors, also implementing the sustainable funding principles;

b. The development of microfinance products and/or services in accordance with business needs so as to support increased access to business funding by Micro, Small and Medium Enterprises (MSMEs). To improve the ability of banks including Islamic banking to reach people who have not yet or lacked financial access, this can be done through inclusive financial initiatives and branchless banking in the framework of inclusive finance;

c. The development of information technology infrastructure to be more optimal and still be able to guarantee the security and reliability of application and data / information services;

Nowadays, a digital economy as a social and economic activity based on technology and the Internet has become part of global behavior. The definition of digital economy is the amalgamation of several general purpose technologies (GPTs) and the range of economic and social activities carried out by people over the internet and related technologies are based on (broadband, routers), the devices that are used for access (computer, smartphones) the applications they power and the functionality they provide (loT, data analytics, cloud computing)[8]

In Indonesia, the digital economy has made it into various walks of life in all ages. Blending people today with the digital economy occurs because of the perceived comfort of a technology-based economy that greatly facilitates human work. The development of the digital economy is also included in the emergence of financial technology, where the existence of the digital economy is stimulating the growth of financial technology.

The development of the digital economy also expected to be felt by all levels of public in Indonesia. However, the main challenges are how to reduce the disparity in the infrastructure of communication and information technology (ICT) in rural and disadvantaged areas and to increase the use of the Internet for productive activities and digital literacy. This time the potential business in the digital era is very wide-open, especially for the creative industry. Financial technologies platforms are one of the impacts from digital economy development that continue to grow become a way out for micro, small and medium enterprises (MSMEs) to obtain a financing. Bank Indonesia, as the largest financial provider in Indonesia, inevitably has to innovate, especially related to the use of technology for bank services for its customers.

Based on the National Inclusive financial strategy, there are 6 Pillars that will become the strategy, those pillars are:

Pillar 1: Financial Education

Pillar 2: Public Financial Facilities

Pillar 3: Mapping financial Information

Pillar 4: Supporting Policies/Regulations

Pillar 5: intermediation and distribution channel

Pillar 6: Consumer Protection

This study will analyze the stages that taken by authority in order to realize financial inclusive. Financial inclusion is important to improving the livelihoods of the poor and disadvantaged. Providing people in developing countries with access to financial services, such as payments, savings, insurance and credit, helps them to manage their financial obligations and build better futures for their families while also supporting broad economic growth, development and poverty reduction.[9] Financial inclusive has a several purposes such as: increasing the opportunities and abilities 
of the public within access and utilize financial services, providing financial products and services that can fulfills public needs, increase the knowledge and sense of security within the community use of financial services; Strengthening the synergy between stakeholders; Encourage the development of financial inclusion for support the achievement of Sustainable Development Goals (SDGs) in Indonesia.

There are a number of inclusive financial target groups in Indonesia including: poor with the lowest income, poor but still working, not poor, domestic and international migrant workers, women, and residents of remote areas. In order to realize the financial independence of the community and support efforts to increase equity in development, the Financial Services Authority (OJK) encourages the expansion of financial services sector products and services to all levels of society, including through the development of microfinance products and services, financial services without offices (branchless banking) and a comprehensive financial education.

Branchless banking is Office less Financial Services in the Framework of Finance Inclusive, which is a program to provide banking services and / or other financial services through collaboration with other parties (bank agents) and is supported by the use of information technology.[10]

Through Branchless banking, it enables banking services to reach all levels of society throughout Indonesia by providing financial products that are simple, easy to understand and in accordance with the needs of the public who cannot yet reach financial services.

Through Branchless banking all levels of Indonesia society allow to reach banking services throughout by providing financial products that are simple, easy to understand and in accordance with the needs of people who have not been able to reach the current financial services. Due to increasing number of members of the various community in various regions in Indonesia can use the financial services/banking, economic activity is expected that people can more easily so as to encourage economic growth and equitable development between regions in Indonesia, especially among rural - city

To expand the financial access, Banks also develop their financial products and/or services such as developing banking product tailored to the needs of MSMEs. The innovative of new financial products connected to the needs of MSMEs that required access. OJK will urge the banking industry, including sharia banks, to develop micro financial product and services. The Efforts to develop MSMEs is require greater access and product innovation adapted to MSME characteristics. MSMEs are the backbone of the economy in terms of labor absorption and stimulating local economic activity. MSMEs have also been shown to be tenaciously resilient to shocks

According to Masterplan of Indonesia Financial Services, OJK give a priorities access to a micro small medium enterprise, to develop a micro financial products and/or services that available to all strata and affordable to low income earners and the nascent middle class. In my opinion, through branchless banking can give a credit/loan to MSMEs, that's why OJK is always consistence to increase the utilization of financial product that will suitable to the local communities; such as to develop branchless banking that is a part of financial inclusion. Financial inclusion allows people to save for family needs, borrow to support a business, or build a cushion against emergencies. Having access to financial services is an important step to reduce poverty and inequality. So, branchless banking is one of an alternative method to extend the distribution channel of financial products, offering an integrated distribution model that facilities consumer access to financial services at one location through one source.

The weakness of this financial inclusion program is that the public who will access banking products still requires that a person must complete the application stages such as a form in order to apply the precautionary principle for banks. In view of anti-money laundering laws and $\mathrm{KYC}$ requirements, banks should conduct due diligence on customers. In practice, most people involved in the informal sector such as the MSME business still lack the requirements for proof of population and other administrative evidence. This is will inhibits them from reaching financial products.

\section{CONCLUSION}

The development of the digital economy is also included in the emergence of financial technology, where the existence of the digital economy is stimulating the growth of financial technology. This time the potential business in the digital era is very wide-open, especially for the creative industry. Financial technologies platforms are one of the impacts from digital economy development that continue to grow become a way out for micro, small and medium enterprises (MSMEs) to obtain a financing. Through Financial Technologies also will optimize the branchless banking presence and through branchless banking, the MSMEs will be financed as well. Thus, creating economic growth that is prospering the community, also reduce poverty and inequality.

\section{REFERENCES}

[1] C. K. Liu, "Policy Brief: the Role of Micro-Small and Medium Enterprises in Achieving SDGs,” 2017.

[2] Global Partnership For Financial Inclusion, "G20 High-Level Principles for Digital Financial Inclusion," 2016.

[3] T. Beck, "Financial Inclusion - measuring progress and progress in measuring," 2016.

[4] OJK, Indonesian Financial Services Sector Master Plan I Fostering Growth and Addressing Challenges in the Financial Services Sector, Today and Tomorrow INDONESIAN FINANCIAL SERVICES SECTOR MASTER PLAN. Jakarta, 2015.

[5] T. Durai and G. Stella, "Digital Finance and Its Impact on Financial Inclusion,” J. Emerg. Technol. Innov. Res., vol. 6, no. 1, pp. 122-127, 2019. 
[9] D. W. Arner, R. P. Buckley, and D. A. Zetzsche, "Fintech for Financial Inclusion: A Framework for Digital Financial Transformation,” 2018.

[10] Research and Development (Banking) Department of OJK, Seputar informasi mengenai Layanan Keuangan Tanpa Kantor Dalam Rangka Keuangan Inklusif (LAKU PANDAI). 2015.
[8] B. C. Dahlman, S. Mealy, and M. Wermelinger, "DEV / DOC / WKP ( 2016 ) 6 Unclassified Authorised for publication by Mario Pezzini, Director of the OECD Development Centre .," 2016.
[6] J. Ibrahim, Theory and Methodology of Normative Legal Research. Bayumedia Publishing, 2006.

[7] R. H. Soemitro, Legal Research Methodology and Jurimetry,. Jakarta: Ghalia Indonesia, 1988. 